\title{
Objective Response to Radiation Therapy and Long- Term Survival of Patients with WHO Grade II Astrocytic Gliomas with Known LOH 1p/19q Status
}

\author{
Ali-Reza Fathi', Erik Vassella², Marlene Arnold², Jürgen Curschmann ${ }^{3}$, Michael Reinert ${ }^{1}$, Istvan Vajtai², \\ Joachim Weis ${ }^{2,4}$, Gianluca Deiana', Luigi Mariani ${ }^{1}$
}

\begin{abstract}
Background: WHO grade II gliomas are often approached by radiation therapy (RT). However, little is known about tumor response and its potential impact on long-term survival.

Patients and Methods: Patients subjected to RT were selected from the own database of WHO grade II gliomas diagnosed between 1991 and 2000. The volumetric tumor response after RT was assessed based on magnetic resonance imaging and graded according to standard criteria as complete, partial (PR, $\geq 50 \%$ ), or minor (MR, $25 \%$ to $<50 \%$ ).

Results: There were 24 astrocytomas and three oligoastrocytomas. 21 patients (78\%) were dead at follow-up (mean survival 74 months). None of the patients had chemotherapy. Objective response occurred in 14 patients (52\%, five PR and nine MR) but was not associated with overall survival. The vast majority of the tumors had no loss of heterozygosity (LOH) 1p and/or 19q ( $86 \%$ ). Conclusion: Approximately $50 \%$ of patients with astrocytic WHO grade II gliomas respond to RT despite the absence of LOH for $1 \mathrm{p} / 19 \mathrm{q}$. The potential predictive factors for response and the impact of response on overall survival remain unclear.
\end{abstract}

Key Words: Glioma $\cdot$ Radiation therapy $\cdot$ LOH $\cdot$ Tumor response $\cdot$ MRI

Strahlenther Onkol 2007;183:517-22

DOI $10.1007 / \mathrm{s} 00066-007-1673-6$

\section{Objektives Tumoransprechen nach Radiotherapie und Langzeitüberleben von Patienten mit astrozytären WHO- Grad-II-Gliomen mit bekanntem LOH-1p/19q-Status}

Hintergrund: WHO-Grad-II-Gliome werden oft einer Radiotherapie (RT) zugeführt. Über das objektive Tumoransprechen und seine potentielle Auswirkung auf das Langzeitüberleben ist allerdings wenig bekannt.

Patienten und Methodik: Aus der eigenen Datenbank von WHO-Grad-II-Gliomen wurden die einer RT unterzogenen Patienten eingeschlossen. Das volumetrische Ansprechen nach RT wurde anhand von Magnetresonanztomogrammen gemessen und nach den Standardkriterien eingestuft: komplett, partiell (PR, $\geq 50 \%$ ) oder gering (MR, 25\% bis $<50 \%$ ).

Ergebnisse: Es fanden sich 24 Astrozytome und drei Oligoastrozytome. Kein Patient erhielt eine Chemotherapie. Bei der Nachuntersuchung waren 21 Patienten (78\%) gestorben (mittlere Überlebenszeit: 74 Monate). Ein objektives Ansprechen wurde bei 14 Patienten verzeichnet (52\%, fünf PR und neun MR), was jedoch nicht mit der Gesamtüberlebenszeit korrelierte. Die Mehrheit der Tumoren wies keinen Verlust an Heterozygotie (LOH) 1p/19q auf (86\%).

Schlussfolgerung: Ungefähr 50\% der Patienten mit astrozytären WHO-Grad-II-Gliomen sprechen trotz fehlenden LOH 1p/19q auf eine RT an. Potentielle prädiktive Faktoren für das Tumoransprechen und dessen Einfluss auf die Gesamtüberlebenszeit bleiben unklar.

Schlüsselwörter: Gliome · Radiotherapie $\cdot \mathrm{LOH} \cdot$ Tumoransprechen · MRT

\footnotetext{
${ }^{1}$ Department of Neurosurgery, University Hospital, Inselspital Bern, Switzerland,

${ }^{2}$ Department of Neuropathology, Institute of Pathology, University of Bern, Switzerland,

${ }^{3}$ Department of Radiation Oncology, University Hospital, Inselspital Bern, Switzerland,

${ }^{4}$ Institute of Neuropathology, University Hospital, RWTH Aachen, Germany.
}

Received: October 10, 2006; accepted: April 3, 2007 


\section{Introduction}

Radiation therapy (RT) is frequently used to treat adult patients with supratentorial WHO grade II gliomas $[3,6,7$, $10-12,16,20]$. However, the impact of RT on overall survival is unclear and the data on the frequency, extent and predictive factors of objective tumor response after RT are almost inexistent for this group of patients [4,25]. RT may be administered early after diagnosis (early radiation therapy [eRT]) or when the tumor progresses (delayed radiation therapy [dRT]). It was demonstrated that eRT improves progressionfree survival, but not overall survival, as compared with dRT $[9,21,24,25]$.

Prognostic factors for progression-free and overall survival in WHO grade II glioma patients include young age, good neurologic and overall performance status, small preoperative tumor volume, lack of enhancement on imaging, oligodendroglial histology, and possibly gross total resection [19]. Loss of heterozygosity (LOH) $1 \mathrm{p} / 19 \mathrm{q}$, which is typically but not exclusively associated with an oligodendroglial morphology $[1,18,22,26]$, is clearly emerging as a strong prognosticator of longer overall survival in this group of patients $[14,23$, $24,26]$. Also, $\mathrm{LOH} 1 \mathrm{p} / 19 \mathrm{q}$ is a strong predictor of response to chemotherapy $[1,2,8,23]$ and some data suggest that it may be a predictor of response to RT [1].

In the present study, we analyzed tumor response after RT and long-term survival in a consecutive series of patients with WHO grade II gliomas diagnosed between 1991 and 2000. In these patients we also assessed whether the tumors had LOH 1p36/19q13 or not.

\section{Patients and Methods}

This was an observational, retrospective, single-center study where data on patients with WHO grade II treated at our institution between 1991 and 2000 were collected prospectively.

\section{Clinical and Volumetric Data}

From our database of WHO grade II glioma patients [14, 15] we selected those subjected to RT. The survival data were updated in March 2005 for all patients. None of the patients had received chemotherapy by that time [14]. Digitalized preRT and post-RT magnetic resonance images (MRIs) were interactively analyzed using a dedicated software (NIH Image for Macintosh by Wayne Rasband, modified for use with Windows, (c) 2000 Scion Corporation), as described [15]. Tumor volumes were measured based on the entire region of hyperintensity (compared to normal brain) in T2-weighted and FLAIR MRIs. Tumor response was assessed between 3 and 12 months after RT and defined as minor (MR, reduction by $\geq 25 \%$ to $<50 \%$ of the initial tumor volume), partial (PR, $\geq 50 \%$ ), and complete (CR, no residual tumor) [13]. Progressive disease (PD) was defined as an increase in tumor volume by $\geq 25 \%$. Patients with CR, PR and MR were defined as responders, patients with stable disease (SD) or PD as nonresponders.

\section{Radiation Therapy}

Our center recommends eRT for "high-risk" and dRT for "low-risk" patients [24]. High age ( $>45$ years), large residual tumor ( $>5 \mathrm{~cm}$ cross sectional diameter or $\left.>60 \mathrm{~cm}^{3}\right)$, bihemispheric involvement, midline shift, preoperative neurologic deficits, and a gemistocytic component were considered risk factors for early progression. In presence of two or more risk factors eRT was typically recommended. Delayed RT was performed at tumor progression, if the recurrent tumor was not considered operable. After CT based three dimensional planning, conformal RT was performed with a linear accelerator (6-MV or 15-MV photons) using multiple fields. 54-60 Gy were administered in daily fractions of 1.8-2 Gy to the tumor region and approximately $2 \mathrm{~cm}$ of the adjacent brain but a maximum dose of 52 Gy on the optic nerves.

\section{LOH for Chromosomes 1p36 and 19q13}

Tumor DNA was extracted from formalin-fixed, paraffin-embedded tissue. Reference (normal) DNA was isolated either from the patient's peripheral blood leukocytes or from tumor-free areas of paraffin-embedded specimens after careful microscopic analysis and subsequent dissection. Microsatellite markers for the chromosomal regions 1p36.21-1p36.33 (D1S468, D1S1612, D1S228, D1S214), and 19q13.31-19q13.41 (D19S219, D19S412, D19 HRC) were amplified by polymerase chain reaction, and analyzed for $\mathrm{LOH}$, as described [14].

\section{Statistical Analysis}

Patient and therapy-related factors were tested for a possible correlation with response after RT. Fisher's exact test based on cross-tables was performed to test the influence of age ( $\leq$ and $>40$ years), gender, presence of any oligodendroglial component, presence of a gemistocytic component, 1 p36 and $19 \mathrm{q} 13$ status, and tumor volume ( $\leq$ and $>70 \mathrm{~cm}^{3}$ ). The impact of objective tumor response and of the timing of RT (eRT vs. dRT) on overall survival was analyzed using the unpaired t-test and Kaplan-Meier methods. The level of statistical significance was set at $\mathrm{p}<0.05$ for a two-tailed hypothesis. The software WinSTAT ${ }^{\circledR}$ for Excel 2003 was used for this analysis.

\section{Results \\ Cohort's Characteristics, Timing of Radiotherapy, and Overall Survival}

Out of the 79 patients diagnosed with WHO grade II glioma between 1991 and 2000 at the University Hospital of Bern, Switzerland, 47 received RT. Preoperative, postoperative and follow-up MRI exams for assessment of tumor response and progression were available for 27 patients, who were the focus of the present study.

There were ten female and 17 male patients with a median age of 38 years (mean $42.5 \pm 2.3$ SEM [standard error of mean], range 26-67 years) at the time of diagnosis. The histo- 
logical diagnosis was oligoastrocytoma in three patients and astrocytoma in 24 patients. There was no oligodendroglioma. Early RT was performed in twelve patients after a mean of 4.5 months following diagnosis (range 0-12 months); four patients had three risk factors (see Patients and Methods), seven patients had two risk factors (mainly large residual tumors and age), and one patient requested RT (patient's choice). Delayed RT was administered in 15 patients after a mean of 38 months following diagnosis (range 18-72 months): 14 patients had tumor progression (with a new contrast enhancement in seven of them), one patient requested the treatment (patient's choice).

21 patients $(78 \%)$ were dead at follow-up. The mean overall survival after diagnosis was 74 months (SEM 7.3, range 7-160 months). The mean follow-up of the six survivors was 113 months (range 62-160 months). None of the factors tested was found to be significantly associated with overall survival. However, male gender, dRT, and tumor volumes $\leq 70 \mathrm{~cm}^{3}$ were positively associated with overall survival after diagnosis (Table 1). There was also a trend for longer overall survival in the patients without any evidence of malignant transformation on MRI ( $p=0.13$ for overall survival from the time of diagnosis; $\mathrm{p}=0.1$ for overall survival from the time of RT).

\section{Tumor Response, Predictive Factors, and Surviva}

Overall, 14 patients (five after eRT and nine after dRT) showed an objective tumor response (52\%): a PR in five (18.5\%) and an MR in nine patients (33\%). 13 patients had either SD (ten patients) or PD (three patients). The mean tumor volume was $103 \mathrm{~cm}^{3}$ (SEM 16.6, range 16.6-332 $\mathrm{cm}^{3}$ ) before and $76.7 \mathrm{~cm}^{3}$ (SEM 16.7, range $13-392 \mathrm{~cm}^{3}$ ) after RT. The mean interval to maximum tumor reduction was 6 months after RT (SEM $0.7)$. Tumor regrowth was observed after a mean of 26 months (SEM 3.7). The graph plotting the changes of tumor volume over time after RT is shown in Figure 1.

The LOH analysis for $1 p$ or $19 q$ was conclusive in 22 out of 27 patients $(81.5 \%)$. Overall, only three patients $(13.6 \%)$ had loss of either $1 \mathrm{p}$ (one patient), 19q (one patient), or both (one patient). Tumor response was observed in ten $(52.6 \%$ ) out of 19 patients without LOH 1p and/or 19q. Of the three patients with LOH of $1 p$ and/or $19 q$, one had an MR and two an SD. The number of patients with LOH 1p36 and/or 19q13 (three patients) was insufficient to test an impact on response

Table 1. Statistical analysis for potential predictors of response to radiotherapy (RT) and overall survival. Fisher's exact test based on two-by-two tables revealed no significant association of the analyzed factors with volumetric tumor response after RT. dRT: delayed radiotherapy; eRT: early radiotherapy; GC: gemistocytic component; LOH: loss of heterozygosity; NS: not significant; ODG: oligodendroglial component; SEM: standard error of mean.

Tabelle 1. Statistische Analyse der möglichen prädiktiven Faktoren für das Ansprechen auf Radiotherapie (RT) und die Gesamtüberlebenszeit. Der Fisher's Exact Test, basierend auf $2 \times 2$-Tabellen, ergab keine signifikante Assoziation der analysierten Faktoren mit der volumetrischen Tumorantwort auf RT. dRT: verzögerte/sekundäre Radiotherapie; eRT: frühe Radiotherapie; GC: gemistozytäre Komponente; LOH:Verlust der Heterozygotie; NS: nicht signifikant; ODG: oligodendrogliale Komponente; SEM: Standardfehler des Mittelwertes.

\begin{tabular}{|c|c|c|c|c|c|}
\hline \multirow[t]{2}{*}{ Factor analyzed } & \multicolumn{3}{|l|}{ Response } & \multicolumn{2}{|l|}{ Overall survival } \\
\hline & $\begin{array}{l}\text { Responders } \\
(n=14)\end{array}$ & $\begin{array}{l}\text { Nonresponders } \\
(n=13)\end{array}$ & $\begin{array}{l}\text { p-value } \\
\text { (Fisher's exact test) }\end{array}$ & $\begin{array}{l}\text { Mean survival after } \\
\text { diagnosis months) }\end{array}$ & $\mathrm{p}$-value (t-test) \\
\hline $\begin{array}{l}\text { Age } \leq 40 \text { years } \\
\text { Age }>40 \text { years }\end{array}$ & $\begin{array}{l}9 \\
5\end{array}$ & $\begin{array}{l}7 \\
6\end{array}$ & 0.7 (NS) & $\begin{array}{ll}72.4 & ( \pm 6.9 \text { SEM }) \\
77.7 & ( \pm 16.7 \text { SEM })\end{array}$ & 0.74 (NS) \\
\hline $\begin{array}{l}\text { Male } \\
\text { Female }\end{array}$ & $\begin{array}{l}8 \\
6\end{array}$ & $\begin{array}{l}9 \\
4\end{array}$ & 0.7 (NS) & $\begin{array}{ll}84.3 & ( \pm 9.5 \text { SEM }) \\
55.6 & ( \pm 9.3 \text { SEM })\end{array}$ & 0.0559 (NS) \\
\hline $\begin{array}{l}\text { ODG } \\
\text { No ODG }\end{array}$ & $\begin{array}{r}0 \\
14\end{array}$ & $\begin{array}{r}3 \\
10\end{array}$ & 0.69 (NS) & a & \\
\hline $\begin{array}{l}\text { GC } \\
\text { NO GC }\end{array}$ & $\begin{array}{l}5 \\
9\end{array}$ & $\begin{array}{l}6 \\
7\end{array}$ & 0.7 (NS) & $\begin{array}{ll}70.1 & ( \pm \text { SEM } 7.5) \\
76.1 & ( \pm \text { SEM 11.4 })\end{array}$ & 0.69 (NS) \\
\hline $\begin{array}{l}\text { Tumor volume } \leq 70 \mathrm{~cm}^{3} \\
\text { Tumor volume }>70 \mathrm{~cm}^{3}\end{array}$ & $\begin{array}{l}6 \\
8\end{array}$ & $\begin{array}{l}9 \\
4\end{array}$ & 0.25 (NS) & $\begin{array}{ll}82.5 & ( \pm \text { SEM } 10.2) \\
62.7 & ( \pm \text { SEM 9.9) }\end{array}$ & 0.18 (NS) \\
\hline $\begin{array}{l}\text { eRT } \\
\text { dRT }\end{array}$ & $\begin{array}{l}5 \\
9\end{array}$ & $\begin{array}{l}7 \\
6\end{array}$ & 0.45 (NS) & $\begin{array}{l}60.58( \pm \text { SEM } 10.1) \\
84.13( \pm \text { SEM 9.8) }\end{array}$ & 0.11 (NS) \\
\hline $\begin{array}{l}\text { LOH 1p36 } \\
\text { No LOH } 1 \text { p36 }\end{array}$ & $\begin{array}{r}1 \\
11\end{array}$ & $\begin{array}{l}1 \\
8\end{array}$ & 1 (NS) & a & \\
\hline $\begin{array}{l}\text { LOH 19q13 } \\
\text { No LOH 19q13 }\end{array}$ & $\begin{array}{r}1 \\
10\end{array}$ & $\begin{array}{l}1 \\
7\end{array}$ & 1 (NS) & a & \\
\hline $\begin{array}{l}\text { Survival after XRT } \leq 60 \text { months } \\
\text { Survival }>60 \text { months }\end{array}$ & $\begin{array}{l}9 \\
5\end{array}$ & $\begin{array}{l}9 \\
4\end{array}$ & 1 (NS) & $\begin{array}{l}9 \\
4\end{array}$ & 1 (NS) \\
\hline $\begin{array}{l}\text { Responders } \\
\text { Nonresponders }\end{array}$ & & & & $\begin{array}{l}79.86( \pm \text { SEM } 11.1) \\
67 \quad( \pm \text { SEM 9.42) }\end{array}$ & 0.39 (NS) \\
\hline
\end{tabular}

alow data available for t-test analysis 
or survival ( $\mathrm{p}=1$, Fisher's exact test). No other factors were associated with tumor response (Table 1).

The mean overall survival after diagnosis was longer for responders than for nonresponders ( 80 months \pm 11 SEM vs. 67 months \pm 9.4 SEM). However, the difference did not reach statistical significance (t-test, Mann-Whitney test). This find-
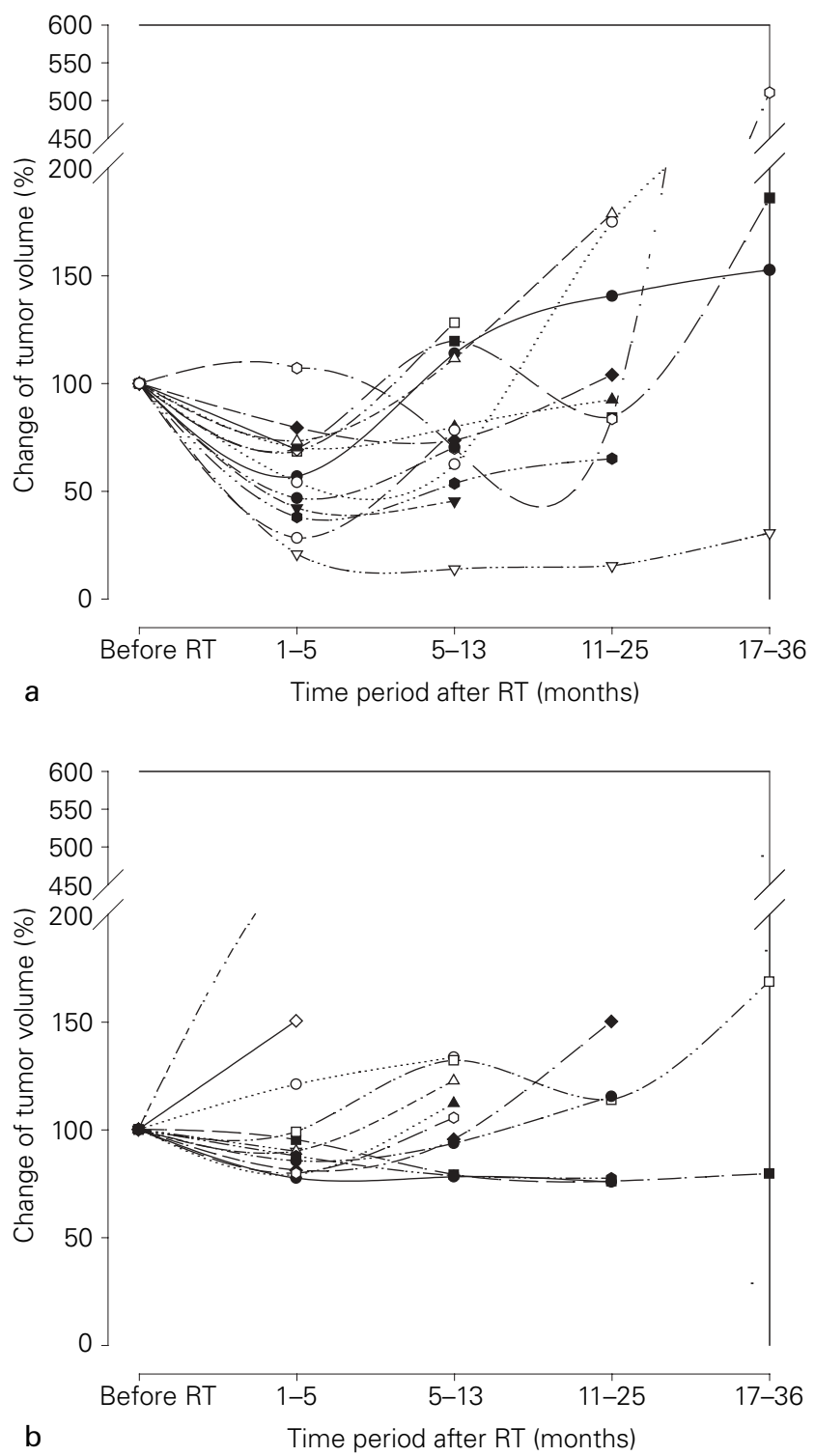

Figures 1a and 1b. Changes in tumor volume after RT are shown for the 14 responders (a) and the 13 nonresponders ( $b$; see Patients and Methods). Please note that 10 out of 13 nonresponders had stable disease according to the definition but nevertheless showed a reduction in tumor volume after RT.

Abbildungen $\mathbf{1 a}$ und $\mathbf{1 b}$. Veränderungen des Tumorvolumens nach RT für 14 Responder (a) und 13 Nonresponder (b; see „Patients and Methods"). Man beachte, dass zwar 10 der 13 Nonresponder gemäß Definition einen unveränderten Volumenverlauf hatten; dennoch zeigte sich bei diesen Patienten eine Tumorvolumenreduktion nach der RT. ing was confirmed by the Kaplan-Meier analysis (Figure 2; $\mathrm{p}=0.33$ ). Also, the overall survival after RT (mean 51 months \pm 6.3 SEM, range 7-117 months) was no different in responders and nonresponders (Figure 2; $\mathrm{p}=0.9$ ). Comparing the seven patients with MRI evidence of malignant transformation with those without this evidence did not reveal significant differences in terms of tumor response after RT ( $\mathrm{t}$-test, $\mathrm{p}=0.8-0.9)$.

\section{Discussion}

To our knowledge, this is the first study analyzing objective tumor response in a cohort of adult patients with WHO grade II gliomas subjected to RT. A reduction in tumor volume after RT was observed in approximately $90 \%$ of the patients. The reduction in tumor volume met the criteria of an objective tumor response in 14 out of 27 patients (52\%). Tumor response reached its maximum approximately 6 months after RT, a finding that matches well what has been reported for pediatric low-grade gliomas [4].

A potential problem with our approach of measuring the tumor volume based on MRI [15] is that hyperintensity changes on T2-weighted and FLAIR images, especially in the long-term follow-up, can be side effects of radiation [5]. Even if postirradiation changes might interfere in the evaluation of tumor progression after RT in the long term, they should not influence the assessment of tumor response, which is characterized by a reduction of the T2-hyperintense, neoplastic regions relatively early after treatment.

None of the factors tested as potential predictors of tumor response were statistically significant. Bauman et al. suggested a positive association between $\mathrm{LOH} 1 \mathrm{p}$ and survival after RT in oligodendroglioma patients [1]. LOH 1p/19q was a rare event in our series, as expected since the vast majority of the tumors were astrocytomas $[17,18]$. The low incidence of $\mathrm{LOH} 1 \mathrm{p} / 19 \mathrm{q}$ prevented us from assessing its potential, positive predictive value for response to RT. However, we could show, that an objective tumor response after RT occurs in approximately half of the patients despite the absence of LOH 1p/19q. This finding may become important for patients' management in the future. The ongoing, cooperative, EORTC trial 22033, in which patients with WHO grade II supratentorial gliomas are stratified according to the $1 \mathrm{p}$ status and randomized to receive either $\mathrm{RT}$ or temozolomide has the potential for elucidating the predictive role of $\mathrm{LOH} 1 \mathrm{p}$ for RT in the future.

The lack of a significant survival advantage for responders over nonresponders is somewhat surprising in the present series. The relatively small number of patients is a possible explanation (type 1 error). However, the length of followup, with $>75 \%$ of the patients having died within that follow-up, and the absence of a trend for a longer overall survival after $\mathrm{RT}$ in the responders suggest the validity of this finding. In fact, the major determinant of overall survival in patients with WHO grade II gliomas is the occurrence of ma- 

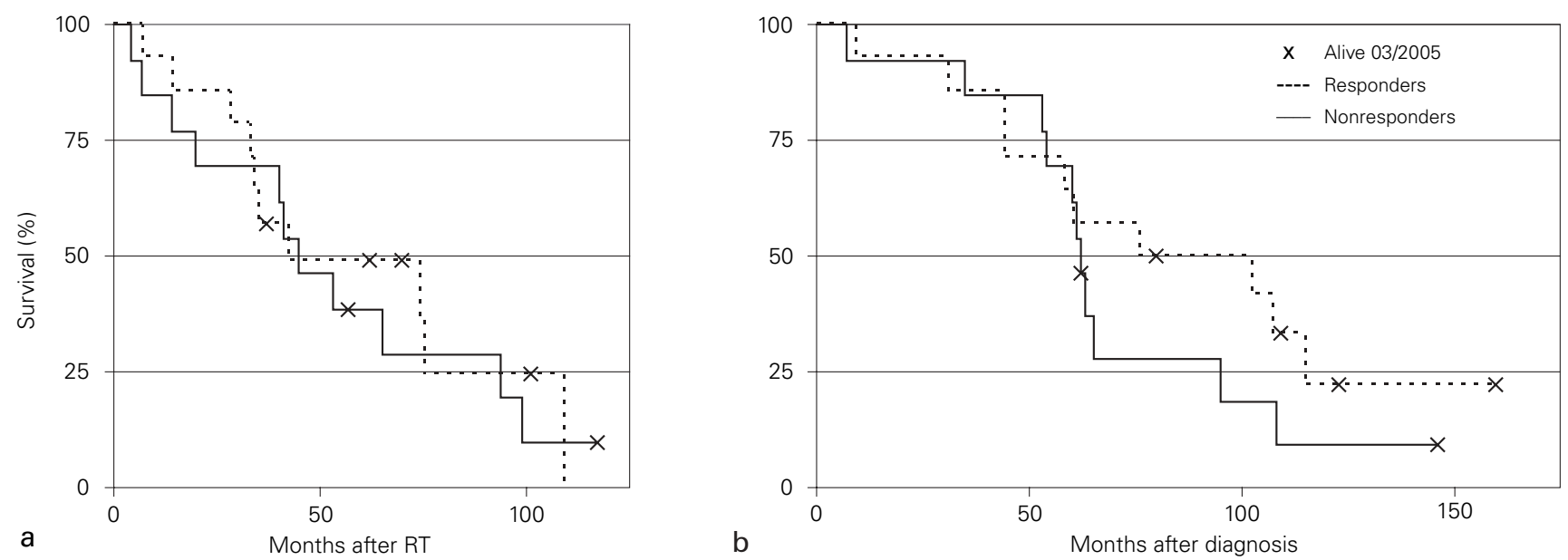

Figures $\mathbf{2 a}$ and $\mathbf{2 b}$. Kaplan-Meier curves of overall survival after RT (a) and after diagnosis (b) are shown for responders and nonresponders. Although a survival advantage after diagnosis is visible for the responders, it is not statistically significant (log-rank test, $p=0.33$ ).

Abbildungen $2 \mathbf{2 a}$ und $\mathbf{2 b}$. Die Kaplan-Meier-Kurven der Gesamtüberlebenszeit nach RT (a) und nach Diagnosestellung (b) für Responder und Nonresponder. Obwohl es für die Responder einen Vorteil in der Gesamtüberlebenszeit nach der Diagnosestellung gibt, zeigt sich statistisch kein signifikanter Unterschied (log-rank test, $p=0,33$ ).

lignant transformation, as suggested by the large cooperative study showing that RT can prolong the progression free survival but not the overall survival of WHO grade II glioma patients [25]. Even in a small series like ours, we found a clear trend for a shorter overall survival in patients with a "high-risk" profile for malignant transformation, that is in patients selected for eRT $(n=12)[25]$ and in patients with a new contrast enhancement before dRT $(n=7)$. Altogether, these data suggest that RT does not influence the cascade of events eventually leading to the malignant transformation of a WHO grade II glioma, which eventually determines overall survival.

\section{Conclusion}

We demonstrated that approximately half of the patients with a WHO grade II glioma show an objective response after RT, even in the absence of $\mathrm{LOH} \mathrm{1p/19q.} \mathrm{The} \mathrm{impact} \mathrm{of} \mathrm{response} \mathrm{to}$ $\mathrm{RT}$ on overall survival and the factors predicting response to $\mathrm{RT}$ remain unclear.

\section{References}

1. Bauman GS, Ino $Y$, Ueki K, et al. Allelic loss of chromosome $1 p$ and radiotherapy plus chemotherapy in patients with oligodendrogliomas. Int J Radiat Oncol Biol Phys 2000;48:825-30.

2. Cairncross JG, Ueki K, Zlatescu MC, et al. Specific genetic predictors of chemotherapeutic response and survival in patients with anaplastic oligodendrogliomas. J Natl Cancer Inst 1998;90:1473-9.

3. Combs SE, Gutwein S, Thilmann C, et al. Reirradiation of recurrent WHO grade III astrocytomas using fractionated stereotactic radiotherapy (FSRT). Strahlenther Onkol 2005;181:768-73.

4. Fisher BJ, Bauman GS, Leighton CE, et al. Low-grade gliomas in children: tumour volume response to radiation. Neurosurg Focus 1998;4:e5.

5. Fuss M, Wenz F, Scholdei R, et al. Radiation-induced regional cerebral blood volume ( $\mathrm{rCBV}$ ) changes in normal brain and low-grade astrocytomas: quantification and time and dose-dependent occurrence. Int J Radiat Oncol Biol Phys 2000;48:53-8.
6. Grabenbauer GG, Roedel CM, Paulus W, et al. Supratentorial low-grade glioma: results and prognostic factors following postoperative radiotherapy. Strahlenther Onkol 2000;176:259-64.

7. Heesters M, Molenaar W, Go GK. Radiotherapy in supratentorial gliomas. A study of 821 cases. Strahlenther Onkol 2003;179:606-14.

8. Hoang-Xuan K, Capelle L, Kujas M, et al. Temozolomide as initial treatment for adults with low-grade oligodendrogliomas or oligoastrocytomas and correlation with chromosome 1p deletions. J Clin Oncol 2004;22:3133-8.

9. Karim AB, Afra D, Cornu P, et al. Randomized trial on the efficacy of radiotherapy for cerebral low-grade glioma in the adult: European Organization for Research and Treatment of Cancer study 22845 with the Medical Research Council study BR04: an interim analysis. Int J Radiat Oncol Biol Phys 2002;52:316-24.

10. Kleihues P, Davis RL, Ohgaki H, et al. Diffuse astrocytoma. In: Kleihues $P$, Cavenee WK, eds. Pathology and genetics of tumours of the nervous system. Lyon: IARC Press, 2000:22-6.

11. Kocher M, Kunze S, Eich HT, et al. Efficacy and toxicity of postoperative temozolomide radiochemotherapy in malignant glioma. Strahlenther Onkol 2005; 181:157-63.

12. Kortmann $\mathrm{RD}$, Jeremic $B$, Weller $M$, et al. Immediate postoperative radiotherapy or "watch and wait" in the management of adult low-grade glioma? Strahlenther Onkol 2004;180:408-18.

13. Macdonald DR, Cascino TL, Schold SC Jr, et al. Response criteria for phase II studies of supratentorial malignant glioma. J Clin Oncol 1990;8:1277-80.

14. Mariani L, Deiana G, Vassella E, et al. Loss of heterozygosity $1 p 36$ and $19 q 13$ is a prognostic factor for overall survival in patients with diffuse WHO grade 2 gliomas treated without chemotherapy. J Clin Oncol 2006; 24:4758-63.

15. Mariani $L$, Siegenthaler $P$, Guzman $R$, et al. The impact of tumour volume and surgery on the outcome of adults with supratentorial WHO grade II astrocytomas and oligoastrocytomas. Acta Neurochir (Wien) 2004;146:441-8.

16. Nowak Sadzikowska J, Glinski B, Szpytma T, et al. Postoperative irradiation of incompletely excised gemistocytic astrocytomas. Clinical outcome and prognostic factors. Strahlenther Onkol 2005;181:246-50.

17. Ohgaki $\mathrm{H}$, Kleihues P. Population-based studies on incidence, survival rates, and genetic alterations in astrocytic and oligodendroglial gliomas. J Neuropathol Exp Neurol 2005;64:479-89.

18. Okamoto Y, Di Patre PL, Burkhard C, et al. Population-based study on incidence, survival rates, and genetic alterations of low-grade diffuse astrocytomas and oligodendrogliomas. Acta Neuropathol (Berl) 2004;108:49-56.

19. Pignatti F, van den Bent M, Curran D, et al. Prognostic factors for survival in adult patients with cerebral low-grade glioma. J Clin Oncol 2002; 20:2076-84 
20. Schueller P, Micke 0, Palkovic $S$, et al. 12 years' experience with intraoperative radiotherapy (IORT) of malignant gliomas. Strahlenther Onkol 2005; 181:500-6.

21. Shaw E, Arusell R, Scheithauer B, et al. Prospective randomized trial of low- versus high-dose radiation therapy in adults with supratentorial lowgrade glioma: initial report of a North Central Cancer Treatment Group/Radiation Therapy Oncology Group/Eastern Cooperative Oncology Group study. J Clin Oncol 2002;20:2267-76.

22. Smith JS, Alderete B, Minn $Y$, et al. Localization of common deletion regions on $1 p$ and $19 q$ in human gliomas and their association with histological subtype. Oncogene 1999;18:4144-52.

23. Stupp R, Hegi ME, van den Bent MJ, et al. Changing paradigms - an update on the multidisciplinary management of malignant glioma. Oncologist $2006 ; 11: 165-80$.

24. Stupp R, Janzer RC, Hegi ME, et al. Prognostic factors for low-grade gliomas. Semin Oncol 2003;30:23-8.

25. Van den Bent MJ, Afra D, De Witte 0 , et al. Long-term efficacy of early versus delayed radiotherapy for low-grade astrocytoma and oligodendroglioma in adults: the EORTC 22845 randomised trial. Lancet 2005;366:985-90.
26. Van den Bent M, Chinot OL, Cairncross JG. Recent developments in the molecular characterization and treatment of oligodendroglial tumours. Neurooncology 2003;5:128-38.

Address for Correspondence

Luigi Mariani, MD

Vice-Chairman

Department of Neurosurgery

Inselspital

3010 Bern

Switzerland

Phone (+41/31) 632-2486, Fax -0432

e-mail: luigi.mariani@insel.ch 